\title{
POLA ASUH ORANGTUA BERHUBUNGAN DENGAN TINGKAT KEBERHASILAN TOILET TRAINING PADA ANAK USIA PRA SEKOLAH
}

\author{
Moomina Siauta*, Selpina Embuai \\ Fakultas Kesehatan, Universitas Kristen Indonesia Maluku, Jln Ot Pattimaipauw, Talake Kecamatan, Nusaniwe, Kel \\ Wainitu, Nusaniwe, Kota Ambon, Maluku, Indonesia, 97115 \\ *moominasiauta@gmail.com
}

\begin{abstract}
ABSTRAK
Kegagalan toilet training mengakibatkan anak tidak percaya diri, rendah diri, malu berhubungan sosial dengan temannya. Tujuan penelitian mengetahui hubungan pola asuh orang tua dengan tingkat keberhasilan toilet training pada anak usia pra-sekolah di TK Dharma Wanita Tunggul Wulung. Desain penelitian ini observasional analitik dengan pendekatan study cross sectional. Sampel diambil dengan menggunakan teknik purposif sampling berdasarkan kriteria inklusi sebanyak 35 responden. Pengumpulan data menggunakan kuesioner. Data dianalisis dengan korelasi chi-square Dari hasil penelitian didapatkan responden yang menggunakan pola asuh demokratis sebanyak $71,4 \%$, pola asuh permisif sebanyak $25,7 \%$, pola asuh otoriter sebanyak $2.9 \%$, pola asuh penelantar sebanyak $0 \%$. Sedangkan untuk tingkat keberhasilan yang berhasil sebanyak $34,3 \%$, cukup berhasil sebanyak $65,7 \%$. Setelah dianalisis dengan korelasi chi-square diperoleh hasil nilai korelasi positif 0.403 dengan signifikansi $\alpha(0.034<0.050)$. Semakin ke arah pola asuh demokratis penerapan toilet training akan berhasil sedangkan semakin ke arah pola asuh penelantar penerapan toilet training kurang berhasil.
\end{abstract}

Kata kunci: anak usia pra sekolah, pola asuh, toilet training

\section{PARENTING STYLE RELATED TO THE SUCCESS OF TOILET TRAINING IN PRE- SCHOOL AGE CHILDREN}

\begin{abstract}
Therefore parent building for independence of children is needed that was realized by toilet training. Toilet training's failure can result the children in feeling inferior, unconscionable and ashamed to communicate friendliness. This research was aimed to know the relation between parent's way of care with degree of toilet training success for children at pre-school age in TK Dharma Wanita Tunggul Malang. Design of this research was analytic observational using approach cross sectional study. Samples were selected using purposive sampling base on inclusive criterion as much as forty respondents. Data were collected using questioner then analysed with correlation of chi-square. From the result of research it was got that the respondent using the way of democratize care was $71,4 \%$, the way of permissive care was $25,7 \%$, the way of authoritative care was $2,9 \%$, the way of neglect care was $0 \%$. Whereas by degree success to success was $34,3 \%$, enough success was 65,7\%,. After analyzed using correlation of chi-square it was got positive correlation 0.403 with significance $\alpha(0.034<0.050)$. It can be concluded that there was significance relation between the parent's way of care and degree of toilet training success for children in pre-school age at TK Dharma Wanita Tunggul Wulung Malang. The more democratic care the application of toilet training the more success while the more neglect care the application of toilet training the less success.
\end{abstract}

Keywords: pre-school, the way of care, toilet training

\section{PENDAHULUAN}

Dampak kegagalan dalam toilet training memberikan pengaruh pada anak sehingga anak tidak percaya diri, rendah diri, malu, hubungan sosial dengan teman-temannya terganggu, anak berkepribadian ekspresif dimana anak menolak untuk latihan toilet training, emosional, cenderung ceroboh dan sesuka hati dalam melakukan kegiatan sehari-hari. 
Orang tua memiliki peran yang sangat penting dalam upaya mengembangkan pribadi anak, dimana keluarga merupakan lingkungan primer bagi setiap individu sejak lahir sampai tiba masanya untuk meninggalkan rumah dan membentuk keluarga sendiri. Sebelum anak mengenal lingkungan yang lebih luas, terlebih dahulu anak mengenal lingkungan keluarganya melalui pengenalan norma-norma dan nilai-nilai dalam keluarga untuk dijadikan bagian dari pribadinya melalui proses pengasuhan. Efek dukungan sosial keluarga terhadap kesehatan dan kesejahteraan saling berkaitan. Pengaruh positif dari dukungan sosial keluarga adalah pada penyesuaian terhadap kejadian dalam kehidupan yang penuh stres (Setiadi,2008). Dalam proses toilet training, dimana anak belajar untuk mengendalikan buang air kecil dan buang air besar, dukungan keluarga diperlukan untuk menciptakan suasana yang kondusif dalam proses belajar anak.

Baumrind mengatakan bahwa setiap pola asuh yang diterapkan memiliki akibat positif dan negatif. Berdasarkan salah satu kelemahan atau pun kelebihan dari pola asuh orang tua yaitu salahnya otoriter, maka akibat negatif yang timbul pada pola asuh ini akan cenderung lebih dominan. Hal yang senada juga disampaikan oleh Bjorklund yang mengatakan bahwa pola asuh otoriter menjadikan seorang anak menarik diri dari pergaulan serta tidak puas dan tidak percaya terhadap orang lain. Namun, tidak hanya akibat negatif yang ditimbulkan, tetapi juga terdapat akibat positif atau kelebihan dari pola asuh otoriter yaitu anak yang dididik akan menjadi disiplin yakni menaati peraturan. Meskipun, anak cenderung disiplin hanya di hadapan orang tua.
Dan pola asuh orang tua sangatlah berpengaruh terhadap penerapan aturan, khususnya pada keberhasilan toilet traning.

Data untuk studi pendahuluan yang di ambil di TK Dharma Wanita Malang, terdapat dua kelas yang terbagi kelas A berjumlah 20 siswa, dan kelas B berjumlah 14. Menurut pihak TK yang mengajar di TK tersebut mengatakan beberapa siswa yang mengalami enuresis (ngompol) dalam kelas A terdapat 6 siswa dan kelas B sekitar 5 siswa dari keseluruhan siswa yang ada di TK tersebut, sehingga hal ini menjadi dasar awal dilakukannya penelitian lebih lanjut pada anak prasekolah dengan keterkaitannya dengan ajaran toilet traning dan pola asuh masing-masing siswa yang didapatkan dirumah, sehingga dapat disimpulkan bagaimana hasil dari keberhasilan toilet traning atau tidaknya siswa di TK Dharma Wanita Tunggul Wulung Malang. Tujuan penelitian ini adalah untuk mengetahui hubungan pola asuh orang tua dengan tingkat keberhasilan toilet traning pada anak usia pra sekolah

\section{METODE}

Desain penelitian ini observasional analitik dengan pendekatan study cross sectional. Sampel diambil dengan menggunakan teknik purposif sampling berdasarkan kriteria inklusi sebanyak 35 responden. Pengumpulan data menggunakan kuesioner yang telah diuji validitas dan reabilitasnya. Data dianalisis dengan korelasi chisquare

\section{HASIL}

Hasil penelitian sebagai berikut.

Tabel 1.

Hubungan antara pola asuh dengan tingkat keberhasilan toilet training pada anak usia pra-sekolah

\begin{tabular}{lccccc}
\hline \multirow{3}{*}{ Pola Asuh } & \multicolumn{5}{c}{ Tingkat Keberhasilan Toilet Training } \\
\cline { 2 - 6 } & $\begin{array}{c}\text { Tidak } \\
\text { Berhasil } \\
\mathrm{f}(\%)\end{array}$ & $\begin{array}{c}\text { Kurang } \\
\text { Berhasil } \\
\mathrm{f}(\%)\end{array}$ & $\begin{array}{c}\text { Cukup } \\
\text { Berhasil } \\
\mathrm{f}(\%)\end{array}$ & $\begin{array}{c}\text { Berhasil } \\
\mathrm{f}(\%)\end{array}$ & $\begin{array}{c}\text { Total } \\
\mathrm{f}(\%)\end{array}$ \\
\hline Penalantar & $0(0)$ & $0(0)$ & $0(0)$ & $0(0)$ & $0(0)$ \\
\hline Permisif & $0(0)$ & $0(0)$ & $4(11,4)$ & $5(14,3)$ & $9(25,7)$ \\
\hline Otoriter & $0(0)$ & $0(0)$ & $0(0)$ & $1(2,9)$ & $1(2,9)$ \\
\hline Demokratis & $0(0)$ & $0(0)$ & $19(54,3)$ & $6(17,1)$ & $25(71,4)$ \\
\hline
\end{tabular}

Tabel 1. di atas diketahui bahwa dari 35 responden yaitu orang tua dan anak usiaprasekolah TK Dharma Wanita Tunggul Wulung Malang, 23 responden termasuk dalam tingkat keberhasilan toilet training kategori cukup berhasil, dan 12 responden termasuk dalam tingkat keberhasilan toilet training kategori

berhasil.

Responden termasuk dalam tingkat keberhasilan toilet training kategori cukup berhasil sebanyak 23 responden, 19 responden orang tua di antaranya memilikipola asuh kategori demokratis, dan 4 responden orang tua memiliki pola asuh kategori 
permisif. Responden termasuk dalam tingkat keberhasilan toilet training kategori berhasil sebanyak 12 responden, 5 responden orang tua di antaranya memiliki pola asuh kategori permisif, 1 responden orang tua memiliki pola asuh kategori otoriter, dan 6 responden orang tua memiliki pola asuh kategori demokratis

AnalisaHubunganPolaAsuh Orang Tuadengan Tingkat KeberhasilanToilet Training : proses pengujian hipotesis dilakukan dengan menggunakan uji Korelasi Chi Square dimaksudkan untuk menguji hubungan pola asuh orang tua dengan tingkat keberhasilan toilet training pada anak usia prasekolah. Dan didapatkan bahwa angka chi-square hasil perhitungan lebih besar dari chi-squaretabel $(6.779>5.992)$ dengan nilai signifikansi lebih kecil dari $\alpha(0.034<0.050)$, maka Ho ditolak dan H1 Diterma maka artinya ada hubungan yang nyata (signifikan) antara pola asuh orang tua dengan tingkat keberhasilan toilet training

\section{PEMBAHASAN}

Hasil tabulasi pada pola asuh penelantar dari 35 responden dengan kategori tidak berhasil, kurang berhasil, cukup berhasil dan berhasil diperoleh presentasi $0(0,0 \%)$. Karena pada pola asuh penelantar ini orang tua memberikan waktu dan biaya yang sangat minim pada anak-anaknya, waktu mereka banyak digunakan untuk keperluan pribadi seperti bekerja, mereka cenderung menelantarkan anak-anak mereka secara fisik maupun psikis. Pengaruh pola asuh ini terhadap anak yaitu anak akan implusif, agresif, kurang bertanggungjawab, tidak mau mengalah, harga diri yang rendah, sering bolos dan sering bermasalah dengan teman-temannya (Buamrind, 2017).

Hasil tabulasi pada pola asuh permisif dari 35 responden dengan kategori cukup berhasil diperoleh presentasi $4(11.4 \%)$ dan 5(14.3\%) dengan kategori berhasil. Karena pada pola asuh ini orang tua lebih memberikan pengawasan yang sangat longgar, memberikan kesempatan pada anak untuk melakukan sesuatu tanpa pengawasanyan cukup dan sangat sedikit bimbingan yang mereka berikan. Pengaruh pola asuh ini terhadap anak yaitu anak agresif, tidak patuh, manja, kurang mandiri dan kurang matang secara sosial (Buamrind, 2017).

Hasil tabulasi pada pola asuh otoriter dari 35 responden dengan kategori berhasil diperoleh presentasi $1(2.9 \%)$. Pada pola asuh ini orang tua lebih cenderung menetapkan standar yang mutlak harus dituruti, biasanya dibarengi dengan ancaman-ancaman. Misalnya kalau tidak makan, maka tidak akan diajak bicara. Pengaruh pola asuh ini terhadap anak yaitu anak menjadi penakut, pendiam, tertutup, tidak berinisiatif, gemar menentang, melanggar norma-norma dan terkesan menarik diri (Buamrind, 2017).

Hasil tabulasi pada pola asuh demokratis dari 35 responden dengan kategori cukup berhasil diperoleh presentasi $19(54.3 \%)$ dan 6(17.1\%) dengan kategori berhasil. Karena pada pola asuh ini orang tua lebih memprioritaskan kepentingan anak, akan tetapi tidak ragu-ragu mengendalikan mereka. Pengaruh pola asuh ini terhadap anak yaitu karakteristik anak-anak yang mandiri, dapat mengontrol diri, mempunyai minat terhadap halhal yang baru dan kooperatif terhadap orang lain. Selain dari hasil tabulasi diatas didapatkan bahwa pola asuh demokratis yang lebih berhasil, hal ini juga didukung oleh beberapa para ahli antara lain :

Menurut (Sulistijan, 2019) Demokratis sendiri memberikan dukungan emosional dengan struktur dan bimbingan pada anak untuk mandirimandirikan anak dalam pemenuhan kebutuhan anak, seperti kebutuhan bertoilet, dimana orang tua dengan memberikan bimbingan dan juga menerapkan berbagai batasan yang akan mengontrol perilaku mereka, seperti dapat mengontrol dalam berkemih/eliminasi. Sedangkan prilaku orang tua yang menggunakan pola asuh permisif bilamana orang tua sangat memanjakan anak yang ditandai dengan adanya kasih sayang yang berlebihan tanpa adanya aturan dalam berprilaku

Menurut (Buamrind, 2017) dimana orang tua dengan pola asuh demokratis, orang tua menerapkan sikap demokratis, kasih sayang, adanya tuntutan serta mengendalikan anak. Contoh perilaku orang tua yang menggunakan pola asuh demokratis "bila saat melatih anak untuk mengontrol buang air kecil anak terlalu asyik bermain maka saya biarkan dulu anak bermain sepuasnya baru berlatih". Sedangkan untuk prilaku orang tua yang menggunakan pola asuh penelantar, orang tuatidak menetapkan aturan yang jelas, kasih sayang yang rendah padaa nak, tidak adanya sikap demokratis dan tuntutan berprestasi sehingga anak tidak terbimbing dibiarkan tumbuh dan berkembang sesuai dengan kemauan anak sendiri sehingga dapat memberikan suatu dampak yang akan merusak anak baik dalam kepribadian maupun kemandirian anak. 
Menurut (Hidayat, 2018) Dari penerapan pola asuh orang tua kepada anak akan ada dampak yang ditunjukan berdasarkan pola asuh itu sendiri, bila ditelah perilaku orang tua yang menggunakan pola asuh demokratis lebih menggunakan komunikasih terbuka, seperti bila mana orang tua menunjukkan adanya kasih sayang, di sertai aturan-aturan dengan menetapkan batas dan kontrol yang mendukung anak pada tindakan konstruktif sehingga tercipta kemandirian pada anak secara alami pada anak itu sendiri. Namun untuk prilaku orang tua yang menggunakan pola asuh otoriter bila mana orang tua menetapkan aturan-aturan yang harus dilaksanakan anak dalam proses pengasuhan tidak di sertai dengan kasih sayang orang tua pada anak maka anak akan menjadi perilaku yang kaku bukan hanya pada dirinya sendiri namun pada lingkungannya, sehingga anak akan susah berbagi kepada orang lain. Sedangkan menurut opini peneliti tentang keempat pola asuh ini pola asuh demokratislah yang lebih baik diterapkan didalam keluarga, Karena pada pola asuh ini orang tua tidak menekan anak-anaknya dengan aturan-aturan yang berdampak pada psikologi anak, tetapi lebih bersifat mengutamakan keinganan anak dengan tetap mengawasi dan menggontrol.

Hasil analisa tersebut dapat kita simpulkan bahwa 19 responden dengan kategori cukup berhasil dan 6 responden dengan kategori berhasil terdapat pada pola asuh demokratis. Sehingga pada pola asuh demokratis dengan kategori cukup berhasil inilah yang mendominasi keberhasilan toilet training pada anak usia prasekolah di TK Dharma Wanita Tunggul Wulung Malang. Sehingga disimpulkan bahwa pola asuh yang relative baik digunakan kepada anak yaitu dengan menerapkan pola asuh demokratis dimana ada aturan yang ditetapkan oleh orang tua namun juga ada sikap keterbukaan dan kasih sayang yang diberikan kepada anak. Hal ini juga didukung oleh beberapa penelitian terdahulu bahwa pola asuh demokratis banyak digunakan dalam mendidik anak.

Penelitian yang dilakukan oleh (Shofa, 2017) mempunyai hasil bahwa tingkat keberhasilan toilet training pada ada anak usia prasekolah dengan menerapkan pola asuh demokratis sebesar $89 \%, 1$ berhasil. Didukung juga oleh penelitian Ustatari (2018) didapatkan $85 \%$ pola asuh demokrtais termasuk dalam kategori berhasil pada toilet training di TK Wahid Hasyim Malang. Dengan demikian bahwa telah terbukti dari beberpaa penelitian bahwa dnegan penerapan pola asuh secara demokratis memberikan dampak yang positif kepada anak, baik secara kognitif dan kesiapan fisik yang dikontrol langsung oleh orang tua serta pengawasan

\section{SIMPULAN}

Terdapat hubungan antara pola asuh dengan tingkat keberhasilan toilet training pada anak usia pra sekolah di TK Dharma Wanita Tunggul Wulung Malang yaitu dengan pola asuh demokratis dan didapatkan nilai signifikansi $(0.034<0.050)$.

\section{DAFTAR PUSTAKA}

Anonymous. (2001). Analisa Pelatihan Perkembangan Toliet Training. Jakarta

Alexandra, Vermandel, (2008), Toilet Training of Healthy Young Todllers: A Randomized Trial Between a Daytime Wetting Alarm and Timed Potty. Journal of Developmental \& Behavioral Pediatrics, 29(3): 191-196

Baumrind, D. (2017). Prototypical Desriptions of 3 Parenting Styles. New York: General Learning Prees

Baumrind, D. (1971). Curent patterns of parental Authority. Journal Development psychology monograph, 4.91-103. Baumrind, D. 2007

Cahyadi. (2007). Model-model penerapan Toilet Training:Jakarta. Salemba

Hawari, Dadang. (2017). Our Children Our Future Dimensi Psikoloreligi Pada Tumbuh Kembang Anak Dan Remaja. Jakarta: Balai Penerbit FKUI.

Hidayat, A. A. (2016). Pengantar Ilmu Keperawatan Anak 1. Jakarta:Salemba Medika.

Hidayat, A. A. (2009). Riset Keperawatan dan Teknik Penulisan Ilmiah Edisi 2. Jakarta:Salemba Medika.

Hidayat, A. A. (2018). Seri Problem Solving Tumbuh Kembang Anak : Siapa Bilang Anak Sehat Pasti Cerdas 6 Kunsci Sukses Mempersiapka Anak Tumbuh Sehat dan Cerdas, Jakarta: PT Elex Media Komputindo

Hethering, E. M., \& Parke, R. D. (2003).Child pyscholog: a contemporary viewpoint (5th ed. Boston: McGraw-hill 
Hockenbery, M. J., Wilson, D., \& Wong, D L (2012), Wong's essential of pediatric nutsing 9: Wong's essential of pediatric nursing. Elsevier Health Sciences

Irma'atus, Sholihah. (2009). Gambaran Pengetahuan ibu tentang kesiapan toilet traning pada anak usia 18-24 bulan di dusun pandantoyo kecematan ngancar kabupaten kediri, KTI Politeknik kesehatan Malang.

Indahana, dkk. (2014). Pemakaian Diapers dan Efek Terhadap Kemampuan Toilet Training pada Anak Usia Toddler. JIKK Vol 5. No. 3 Agustus 2014: Hal: 61-68:

Mufattah. (2008). Pentingnya Toilet Traning pada Anak. Article.

Mujahidatul Musfiroh, dkk. (2014). Jurnal Kesehatan Masyarakat: Kemas 9 (2) (2014), Hal 157-166.

Mami, Andrew. 2007. Faktor-faktor Anak Mengompol. Penelitian Skripsi.

Nursalam. 2003.Konsep \& Penerapan Metodologi Penelitian Ilmu Keperawatan Pedoman Skripsi, Tesis dan Instrument Penelitian Keperawatan. Jakarta: Salemba Medika.

Nototmodjo, Soekidjido, 2007, Metodologi Penelitian Kesehatan, Jakarta : Rineka Cipta.

Petranto. (2006). Analisa Tata cara Pemberian Pola Asuh Orang Tua pada Aanak Sekolah. Jurnal Penelitian. Vol 1 Nomor 5. Hal : 6566.

Septian Andriyani, dkk. (2014). Jurnal Penelitian: Analisis Faktor-faktor Berhubungan Toilet Training pada Anak Prasekolah. Volume 2 Nomor 3. Hal :146-153

Sugiono. (2009). Statistika Untuk Penelitian. Bandung : CV ALFABETA.

Sulistijani, D. (2009). Pengalaman adalah Guru Hebat. Jakarta: Trisbus Agriwidya

Sukadji, S. Dan Badingah, S. (1994). Pola Asuh, Perilaku Agresif Orang Tua dan Kegemaran Sebagai Prediktor Perilaku Agresif. Jurnal Psikologi. Tahun XXI. No 1. Hal 19-27
Tarmudji, T. (2001). Hubungan Pola Asuh Orang Tua Dengan Agresivitas Remaja. Jurnal Penelitian.Vol 7.

Yanti. (2012). Jurnal Penelitian : Penerapan Pola Asuh Orang Tua dengan Kemandirian anak. Vol. 6. Hal: 167-168.

Wong, D. L. (2008).Buku Ajar Keperawatan Pediatrik Wong, edisi 6. Jakarta: ECG, 2008

Heppner, P. P., Wampold, B. E., \& Kivlighan, D. M. (2008). Research Design in Counseling, Third Edition. Belmont: Thomson Higher Education.

Wampold, B. E., \& Kivlighan, D. M. (2008). Research Design Belmont: Thomson Higher Education. 
Jurnal Keperawatan Jiwa Volume 8 No 2 Hal 217 - 222, Mei 2020

FIKKes Universitas Muhammadiyah Semarang bekerjasama dengan PPNI Jawa Tengah 